Soil Environ. 39(1): 50-58, 2020

DOI: $10.25252 / S E / 20 / 132080$

Online ISSN: 2075-1141

Print ISSN: 2074-9546

\title{
Improving yield and quality of maize by different drip-fertigation rates of N, P and $\mathrm{K}$ fertilizers
}

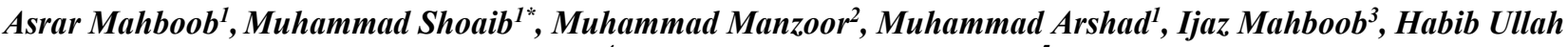 \\ Habib $^{4}$ and Malik Muhammad Akram ${ }^{5}$ \\ ${ }^{1}$ Maize \& Millets Research Institute, Yusafwala \\ ${ }^{2}$ Water Management Research Farm, Renala Khurd-Okara \\ ${ }^{3}$ Soil Fertility Laboratory, Kasur \\ ${ }^{4}$ Water Management Training Institute, Lahore \\ ${ }^{5}$ On-Farm Water Management Punjab, Lahore \\ [Received: January 20, 2020 Accepted: April 02, 2020 Published Online: April 11, 2020]
}

\begin{abstract}
Lower fertilizer use efficiency coupled with conventional irrigation methods has been the issue of agricultural production system in Pakistan contributing to lower crop yields. In this backdrop, an experiment was conducted to investigate the impact of drip-fertigation using different rates of $N, P$ and $K$ fertilizers i.e., $F_{100}$ (100\% of recommended), $F_{75}$ (75\% of recommended), $F_{50}\left(50 \%\right.$ of recommended) and $F_{25}$ (25\% of recommended) on hybrid maize in autumn and spring growing season. Results suggested that number of final harvested plants ha ${ }^{-1}$ decreased by $4.9 \%$ in autumn and $5.85 \%$ in spring season as fertilizer rates decreased from $F_{100}$ to $F_{25}$ while decrease in ears $h^{-1}$ was $5.9 \%$ and $6.05 \%$, respectively. Plant and ear height remained stable with decrease in fertilizer rate from $F_{100}$ to $F_{50}$. On average with $F_{25}$, crop reached maturity 2 days earlier in both autumn and spring seasons, respectively, against $F_{100}$. Ear length and number of grains row ${ }^{-1}$ showed an increasing trend with increasing fertigation rate. Number of rows ear-1 showed significant response only in one growing instance out of four. In both seasons, crop produced or sustained highest fresh ear weight and grain yield $\left(\mathrm{kg} \mathrm{ha}^{-1}\right)$ at $F_{75}$ indicating that a further increment of $25 \%$ nutrients $\left(F_{100}\right)$ would be an excessive rate. Protein and oil \% were also higher at $F_{75}$ treatment in both seasons. Partial factor productivity (PFP) showed a negative relation with increasing fertigation rate however higher PFP values at lower fertilizer rates were economically ineffective. In conclusion, application of $75 \%$ of the recommended $N, P$ and $K$ fertilizers through drip fertigation optimized the grain yield and quality of maize in Punjab.
\end{abstract}

Keywords: NPK, partial factor productivity, protein $\%$, fresh ear weight, quality, oil contents

\section{Introduction}

Pakistan is a dry country in the warm temperate zone where precipitation (except in the northern highlands) averages to less than $250 \mathrm{~mm}$ annually, that decreases from north to south. The Indus basin system is the main source of fresh water in the upper and lower Indus plains. Approximately 170 billion cubic meter (BCM) enters the basin out of which $75 \%$ diverted for irrigation purpose to the canals leaving rest to fall in the sea (GoP, 2014). About $93 \%$ of the total fresh water available in the country is used by agriculture (Qureshi et al. 2009). Due to high temperature, fusty irrigation designs and practices and poor crop management have resulted in $30-40 \%$ delivery efficiency of water from canals to the root zone. Adding to this, Pakistan is the $7^{\text {th }}$ worst hit country by climate change (Eckstein et al., 2019). Rise in temperature is projected in the country that will increase the evaporative demand of the crops further exacerbating the misery of water shortage. Alike, another major key issue in sustainable agricultural production in Pakistan is lower fertilizer use efficiency $(<20 \%)$ owing to low organic matter $(<1 \%)$, fusty fertilizer application techniques, less interest in improving soil health through green manuring etc. (Afzal and Ahmad, 2009). Iqbal et al. (2013) has identified that effective and efficient fertilizer use would be an important strategy to address the problem of intensive agriculture. Therefore, improved and efficient techniques of irrigation and fertilizer application

\footnotetext{
*Email: drmshoaibshah@gmail.com
} 
are indispensable for judicious resource utilization and sustaining the agricultural production system.

According to the $6^{\text {th }}$ population and housing census of Pakistan in 2017, country's population is increasing at $2.4 \%$ annually. To meet the dietary needs of rapidly growing population, crop yield per unit of land has to be increased. This increase can only be achieved through efficient use and management of limited agricultural resources. Of these resources, water and fertilizers are the most important that contribute towards crop yield yet mismanaged at farm level.

Maize has become a very important cereal crop in Punjab after wheat and rice. During 2018-19 maize was cultivated on 899.7 thousand hectares (574.5 autumn and 325.2 spring). In Punjab about $92 \%$ of the total maize is sown under irrigated conditions. Punjab shares 59\% in the total maize cultivated area while $81.42 \%$ of the country's total production. Average yield of maize in Pakistan is 4.31 $\mathrm{t} \mathrm{ha}^{-1}$ which is quite low comparing to other countries that are using their resources efficiently.
Drip irrigation is one of the most efficient irrigation methods that reduces crop water requirement, improves yield and decreases the fertilizer application requirements (Lekakis et al. 2011) and is accepted for crop production in areas of water scarcity (Fanish et al., 2011). Drip irrigation allows the efficient application of fertilizers (dripfertigation) and other agro-chemicals (Pablo et al., 2007). Higher crop yields are achieved by precise irrigation management that generats radial distribution pattern and effective utilization of nutrients (Qureshi et al., 2015). Synchronous application of irrigation with fertilizer reduces inter-plant competition, improves and optimizes the growth and subsequent yield of the crop (Prihar et al., 2000; Wu et al., 2019). Highly localized application of plant nutrients makes the nutrients available for substantial part of the roots. Furthermore, frequent application of nutrients in several little doses makes their optimum utilization, which ensures higher yield. Currently, in Pakistan use of drip irrigation is limited in orchards and lawns however row crops specially cotton, and maize can successfully be grown

Table 1: Average soil characteristic of experimental site

\begin{tabular}{|c|c|c|c|c|c|c|c|}
\hline Soil depth & Ec $(\mathrm{ms} / \mathrm{cm})$ & $\mathbf{p H}$ & OM (\%) & $\begin{array}{l}\text { Avail. P } \\
\text { (ppm) }\end{array}$ & $\begin{array}{l}\text { Avail. K } \\
\text { (ppm) }\end{array}$ & Saturation & Texture \\
\hline \multicolumn{8}{|c|}{ Autumn } \\
\hline $0-15 \mathrm{~cm}$ & 1.1 & 8.2 & 0.62 & 12 & 210 & 41 & Loam \\
\hline $5-30 \mathrm{~cm}$ & 1.4 & 8.4 & 0.48 & 9 & 196 & 38 & Loam \\
\hline \multicolumn{8}{|c|}{ Spring } \\
\hline $0-15 \mathrm{~cm}$ & 1.3 & 8.2 & 0.71 & 14 & 212 & 40 & Loam \\
\hline $5-30 \mathrm{~cm}$ & 1.5 & 8.3 & 0.53 & 9 & 197 & 39 & Loam \\
\hline
\end{tabular}

Table-2: Average monthly maximum and minimum temperature $\left({ }^{\circ} \mathrm{C}\right)$, relative humidity $(\%)$ and rainfall $(\mathrm{mm})$ during the experimental period

\section{Climatic parameter \\ Daily maximum temperature $\left({ }^{\circ} \mathrm{C}\right)$ \\ Daily minimum temperature $\left({ }^{\circ} \mathrm{C}\right)$ \\ $\mathrm{RH} \%$ at 8 a.m. \\ RH $\%$ at 5 p.m. \\ Rainfall (mm) \\ Climatic parameter \\ Daily maximum temperature $\left({ }^{\circ} \mathrm{C}\right)$ \\ Daily minimum temperature $\left({ }^{\circ} \mathrm{C}\right)$ \\ $\mathrm{RH} \%$ at 8 a.m. \\ RH $\%$ at 5 p.m. \\ Rainfall (mm)}

\begin{tabular}{|c|c|c|c|c|c|c|c|c|c|}
\hline \multicolumn{10}{|c|}{ Autumn season } \\
\hline \multicolumn{2}{|c|}{ August } & \multicolumn{2}{|c|}{ September } & \multicolumn{2}{|c|}{ October } & \multicolumn{2}{|c|}{ November } & \multicolumn{2}{|c|}{ December } \\
\hline 2017 & 2018 & 2017 & 2018 & 2017 & 2018 & 2017 & 2018 & 2017 & 2018 \\
\hline 39.67 & 26.48 & 38.43 & 34.56 & 37.52 & 40.26 & 27.51 & 42 & 27.45 & 43.3 \\
\hline 27.93 & 8.89 & 23.76 & 16.29 & 19.77 & 20.26 & 12.88 & 23.45 & 7.21 & 27.1 \\
\hline 62.45 & 84.62 & 66.8 & 79.35 & 71.39 & 61.02 & 84.36 & 44.06 & 82.97 & 45.54 \\
\hline 43.25 & 77.03 & 48.23 & 62.35 & 35.45 & 34.03 & 50.13 & 36.45 & 65.23 & 41.5 \\
\hline 9 & & 74 & 16.8 & - & 3.5 & 2.2 & 4 & 7.6 & \\
\hline \multicolumn{10}{|c|}{ Spring Season } \\
\hline \multicolumn{2}{|c|}{ February } & \multicolumn{2}{|c|}{ March } & \multicolumn{2}{|l|}{ April } & \multicolumn{2}{|l|}{ May } & \multicolumn{2}{|l|}{ June } \\
\hline 2018 & 2019 & 2018 & 2019 & 2018 & 2019 & 2018 & 2019 & 2018 & 2019 \\
\hline 26.48 & 19.11 & 34.54 & 28.03 & 40.26 & 36.6 & 42 & 40.64 & 40.63 & 44.03 \\
\hline 8.89 & 8.17 & 16.29 & 13.45 & 20.56 & 20.4 & 23.45 & 22.29 & 26.60 & 25.76 \\
\hline 84.62 & 83.85 & 79.35 & 73.03 & 61.23 & 55.1 & 44.06 & 50.41 & 49.2 & 46.33 \\
\hline 77.03 & 77.57 & 62.35 & 47.03 & 34.03 & 32.9 & 36.45 & 31.38 & 42.53 & 36.3 \\
\hline 0 & 41.3 & 16.8 & 5.5 & 3.5 & 31.6 & 4 & 31.2 & 64.1 & 1 \\
\hline
\end{tabular}


under drip irrigation system (Ünlüet al., 2011; Wan et al., 2012; Wu et al. 2019).

The concept of fertigation in Punjab is mostly limited to application of urea dissolved in a drum placed at water course from where it trickles in the flowing irrigation water into the field. To achieve the food security while protecting the environment, a fertigation should be optimally used in any irrigation system (Azad et al., 2018). Though myriad of research has investigated the impact of different levels of fertilizers especially $\mathrm{N}$ applied through drip-fertigation on maize yield and quality under different soil types (Fanish et al., 2011; Sampathkumar and Pandian, 2011; Azad et al., 2018; Wu et al., 2019). However, no such study has been conducted in Pakistan, though chunk of the maize crop is cultivated under irrigated conditions.

In the present study, two year field experiments were conducted to find out the effect of simultaneous application of nitrogen, phosphorus and potassium fertilizers with different rates through drip-fertigation on grain yield, quality and partial factor productivity of maize.

\section{Materials and Methods}

\section{Location and Soil}

Experiments were conducted at Water Management Research Farm, Renala Khurd, District Okara that is one of the six major maize growing districts of Punjab province $\left(30.53^{\circ} \mathrm{N}, 73.36^{\circ} \mathrm{E}, 170 \mathrm{~m}\right.$ above sea level). Experiments were carried out in two distinct maize growing seasons i.e., autumn (July-November) and Spring (February-June) for two years (autumn 2017, 2018 and spring 2018, 2019). Weather conditions during the study period are depicted in table 1.

The soil type of the experimental site was loam. To estimate different physico-chemical attributes soil samples were collected from top $0-15 \mathrm{~cm}$ and $15-30 \mathrm{~cm}$ depth separately and analyzed. The average characteristics of presowing soil analysis are given in table 2 .

\section{Field layout}

Treatments were laid out in randomized complete block design with four replications. Sowing was done on $1.05 \mathrm{~m}$ center-to-center wide beds. One seed was planted on premarked spacing of $22.5 \mathrm{~cm}$ on both sides of the beds to achieve 33000 plants acre $^{-1}$. Gross plot size for each treatment was $12.6 \mathrm{~m} \times 5 \mathrm{~m}$ while a net plot size of $3.15 \mathrm{~m} \times$ $4 \mathrm{~m}$ from center of each plot was allocated for data recording. Specifications of drip irrigation system were a main line $60 \mathrm{~mm}$ and sub-main $37 \mathrm{~mm}$ diameter. Drip laterals of $16 \mathrm{~mm}$ diameter with $40 \mathrm{~cm}$ dripper spacing were placed at the center of the bed top while distal end of the lateral was tied and crimped over. Water was supplied with 2.5 to 3.0 bar with a discharge rate of 4 liters $\mathrm{h}^{-1}$.

Table 3: Schedule of nitrogen, phosphorus and potassium fertilizer management according to the treatment

\begin{tabular}{|c|c|c|c|c|c|c|}
\hline \multirow[b]{2}{*}{ Crop growth stage } & \multicolumn{3}{|c|}{ Nutrients kg/ha/day } & \multicolumn{3}{|c|}{ Fertilizer kg/ha/day } \\
\hline & $\mathbf{N}$ & $\mathrm{P}_{2} \mathrm{O}_{5}$ & $\mathrm{~K}_{2} \mathrm{O}$ & Urea & MAP & SOP \\
\hline \multicolumn{7}{|c|}{$100 \%$} \\
\hline Vegetative Phase & 1.77 & 1.36 & 0.78 & 3.27 & 2.23 & 1.57 \\
\hline Flowering Phase & 2.66 & 1.36 & 1.57 & 5.20 & 2.23 & 3.14 \\
\hline Ear Development Phase & 1.77 & 0.00 & 3.14 & 3.85 & 0.00 & 6.27 \\
\hline Grain Development Phase & 0.89 & 0.00 & 1.57 & 1.93 & 0.00 & 3.14 \\
\hline \multicolumn{7}{|c|}{$75 \%$} \\
\hline Vegetative Phase & 1.33 & 1.03 & 0.59 & 2.46 & 1.69 & 1.18 \\
\hline Flowering Phase & 2.00 & 1.03 & 1.18 & 3.90 & 1.69 & 2.36 \\
\hline Ear Development Phase & 1.33 & 0.00 & 2.36 & 2.90 & 0.00 & 4.71 \\
\hline Grain Development Phase & 0.67 & 0.00 & 1.18 & 1.45 & 0.00 & 2.36 \\
\hline \multicolumn{7}{|c|}{$50 \%$} \\
\hline Vegetative Phase & 0.89 & 0.68 & 0.39 & 1.65 & 1.11 & 0.79 \\
\hline Flowering Phase & 1.34 & 0.68 & 0.79 & 2.62 & 1.11 & 1.58 \\
\hline Ear Development Phase & 0.89 & 0.00 & 1.58 & 1.94 & 0.00 & 3.16 \\
\hline Grain Development Phase & 0.45 & 0.00 & 0.79 & 0.97 & 0.00 & 1.58 \\
\hline \multicolumn{7}{|c|}{$25 \%$} \\
\hline Vegetative Phase & 0.45 & 0.34 & 0.20 & 0.82 & 0.56 & 0.39 \\
\hline Flowering Phase & 0.67 & 0.34 & 0.39 & 1.31 & 0.56 & 0.79 \\
\hline Ear Development Phase & 0.45 & 0.00 & 0.79 & 0.97 & 0.00 & 1.58 \\
\hline Grain Development Phase & 0.22 & 0.00 & 0.39 & 0.48 & 0.00 & 0.79 \\
\hline
\end{tabular}




\section{Treatments and Crop husbandry}

Crop water requirement and irrigation scheduling was determined by CropWat 8 model, a decision support tool developed by FAO that helps in calculating the potential Evapotranspiration (based on Penman-Monteith method), in an area taking into account various climatic factors including humidity, wind speed, sunshine hours, and temperature (FAO, 2017).

Seeds were provided with proper moisture up to germination and treatments were applied thereafter. Treatments consist of simultaneous application of four different levels of nitrogen $(\mathrm{N})$, phosphorus $\left(\mathrm{P}_{2} \mathrm{O}_{5}\right)$ and potassium $\left(\mathrm{K}_{2} \mathrm{O}\right)$ fertilizers viz. $100 \%\left(\mathrm{~F}_{100}\right), 75 \%\left(\mathrm{~F}_{75}\right)$, $50 \%\left(\mathrm{~F}_{50}\right)$ and $25 \%\left(\mathrm{~F}_{25}\right)$ of recommended rate $(205-82-205$ $\left.\mathrm{N}-\mathrm{P}_{2} \mathrm{O}_{5}-\mathrm{K}_{2} \mathrm{O} \mathrm{kg} \mathrm{ha}{ }^{-1}\right)$. Detail of treatments is given in Table 3. In autumn maize hybrid 31R88 of Pioneer was planted on $21^{\text {st }}$ and $09^{\text {th }}$ August in 2017 and 2018 while in spring season maize hybrid DK6789 of Bayer Crop Sciences was planted on $12^{\text {th }}$ February and $1^{\text {st }}$ March in 2018 and 2019,

\section{Partial fertilizer productivity (PFP)}

Partial factor productivity (PFP) that is the crop production per unit of nutrient applied describes how a system is productive in relation to its nutrient input (Van Cleemput 2000) was determined by;

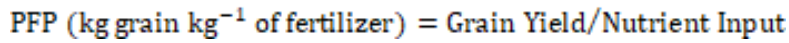
Nutrient input includes $\mathrm{N}+\mathrm{P}_{2} \mathrm{O}_{5}+\mathrm{K}_{2} \mathrm{O}$ in $\mathrm{kg} \mathrm{ha}^{-1}$.

Statistical analysis was done by subjecting the data to ANOVA using SAS statistical Package Program. Separation of means of significantly affected characters was done by Fisher's LSD Test at 5\% probability (Steel and Torrie, 1980).

\section{Results and Discussion}

Harvested plants ha ${ }^{-1}$ in both the seasons were affected by drip-fertigation levels $(p<0.05)$. Across the seasons and years, decrease in fertigation level generally lowered the final stand count (Table 4). In spring, harvested plants only decreased to significant level until drip-fertigation rate was

Table 4: Effect of drip-fertigation of different rates of $\mathrm{N}, \mathrm{P}$ and $\mathrm{K}$ fertilizer on harvested plants ha ${ }^{-1}$ and number of ear ha-1

\begin{tabular}{|c|c|c|c|c|c|c|c|c|}
\hline \multirow{3}{*}{ Treatments } & \multicolumn{4}{|c|}{ Harvested plants ha-1 } & \multicolumn{4}{|c|}{ No. of ears ha- } \\
\hline & \multicolumn{2}{|c|}{ Autumn } & \multicolumn{2}{|c|}{ Spring } & \multicolumn{2}{|c|}{ Autumn } & \multicolumn{2}{|c|}{ Spring } \\
\hline & 2017 & 2018 & 2018 & 2019 & 2017 & 2018 & 2018 & 2019 \\
\hline$F_{100}$ & $61560 \mathrm{a}$ & $77579 \mathrm{a}$ & $85506 \mathrm{a}$ & $84524 \mathrm{a}$ & $50833 \mathrm{a}$ & $73810 \mathrm{a}$ & 82639 & $90278 \mathrm{a}$ \\
\hline $\mathrm{F}_{75}$ & $61905 \mathrm{a}$ & $75198 \mathrm{ab}$ & $85843 \mathrm{a}$ & $83333 \mathrm{a}$ & 50496 a & $73214 \mathrm{a}$ & 84494 & $89087 \mathrm{ab}$ \\
\hline $\mathrm{F}_{50}$ & $59048 \mathrm{~b}$ & $74008 \mathrm{~b}$ & $86181 \mathrm{a}$ & $82341 \mathrm{a}$ & $47619 \mathrm{~b}$ & $72817 \mathrm{ab}$ & 84325 & $86905 \mathrm{~b}$ \\
\hline $\mathrm{F}_{25}$ & $58774 \mathrm{~b}$ & $73413 \mathrm{~b}$ & $81627 \mathrm{~b}$ & $78373 \mathrm{~b}$ & $47012 \mathrm{~b}$ & $70635 \mathrm{~b}$ & 81458 & $82540 \mathrm{c}$ \\
\hline LSD $_{0.05}$ & 1424 & 2505 & 2645 & 3450 & 1074 & 2539 & ns & 2969 \\
\hline
\end{tabular}

Means sharing similar letter are not significantly different from each other ( $p>0.05$ ANOVA followed by Fisher's LSD Test).

respectively. Weeds and insects were controlled by applying proper herbicides and insecticides.

Time of the harvest was determined by appearance of symptoms that include development of black layer at the kernel tip. Number of harvested plants and ears $\mathrm{ha}^{-1}$ were determined by counting the ear bearing plants and ears from net plot and then calculated for hectare. Yield and yield components were determined by harvesting net plot from every treatment and ears were separated and weighed afterward. Grain moisture was determined by Agratonic ${ }^{\mathrm{TM}}$ MT-16 grain moisture tester and subsequently grain yield was expressed at $14 \%$ grain moisture. Ten ears randomly were selected from each plot to determine the ear length, number of rows ear ${ }^{-1}$, number of grains row $^{-1}$. Grain starch, oil and protein content percentages were determined by 'Inframatic 9200', a whole grain near infra-red (NIR) analyzer. decreased beyond $F_{50}$ in both years however in autumn count remained stable up to $\mathrm{F}_{75}$ and thereafter decreased. Decrease in harvested plants ha ${ }^{-1}$ from $F_{100}$ to $F_{25}$ fertilizer level was $4.94 \%$ and $6.32 \%$ in autumn and spring, respectively. Increasing rate of N, P and K fertilizers helped to lower the competition among maize plants and sustained more number of plants to be productive (Wu et al., 2019) while poor stand count in treatments with lower rate of dripfertigation reflects the insufficient nutrients availability for normal plant growth.

Treatment effect on number of ears ha ${ }^{-1}$ was significant $(p<0.05)$ on three instances out of four (Table-4). In these seasons, ear number is linearly related with decreasing fertigation rate. From $F_{100}$ to $F_{25}$, decrease in ear number was $5.9 \%$ across seasons and years however difference between $F_{100}$ and $F_{75}$ was not significant $(p>0.05)$. Ear density is a function of number of plants per unit land and crop management during growth season. Improvement in 
water and nutrient management through drip-fertigation minimized the competition among plants (Wu et al., 2019) therefore treatment with higher fertilizer rates sustained more number of plants hence number of ears.

Plant and ear height are important plant traits linked with production potential of the maize crop. Both the traits were significantly affected by treatments under study $(p<0.05)$. Higher rates of fertilizers increased the plant and ear height (Table-5) though fertigation rates $\left(\mathrm{F}_{100}, \mathrm{~F}_{75}\right.$ and the fertilizer rate increased from $F_{25}$ to $F_{100}$ across the seasons. These results can be explained by availability of sufficient nutrients for plants to grow vigorously that delayed the plant phenology (Dolan et al., 2006 and Khaliq et al., 2008). Plants from $\mathrm{F}_{25}$ reached silking 2.2 and 1.75 days earlier compared to $\mathrm{F}_{100}$ in autumn and spring, respectively, that reflects more profound impact of fertigation rate on crop growth in autumn compared to spring.

Table 5: Effect of drip-fertigation of different rates of $\mathrm{N}, \mathrm{P}$ and $\mathrm{K}$ fertilizer on plant height (cm) and cob height (cm)

\begin{tabular}{|c|c|c|c|c|c|c|c|c|}
\hline \multirow{3}{*}{ Treatment } & \multicolumn{4}{|c|}{ Plant height $(\mathrm{cm})$} & \multicolumn{4}{|c|}{ Cob height (cm) } \\
\hline & \multicolumn{2}{|c|}{ Autumn } & \multicolumn{2}{|c|}{ Spring } & \multicolumn{2}{|c|}{ Autumn } & \multicolumn{2}{|c|}{ Spring } \\
\hline & 2017 & 2018 & 2018 & 2019 & 2017 & 2018 & 2018 & 2019 \\
\hline$F_{100}$ & $195 \mathrm{a}$ & $254 \mathrm{a}$ & $247 \mathrm{a}$ & $252 \mathrm{a}$ & $86 b$ & $114 \mathrm{a}$ & $112 \mathrm{a}$ & $124 \mathrm{a}$ \\
\hline $\mathrm{F}_{75}$ & $198 \mathrm{a}$ & $259 \mathrm{a}$ & $247 \mathrm{a}$ & $254 \mathrm{a}$ & $88 \mathrm{ab}$ & $120 \mathrm{a}$ & $109 \mathrm{ab}$ & $121 \mathrm{a}$ \\
\hline $\mathrm{F}_{50}$ & $197 \mathrm{a}$ & $264 \mathrm{~b}$ & $242 \mathrm{a}$ & $250 \mathrm{a}$ & $91 \mathrm{a}$ & $118 \mathrm{a}$ & $115 \mathrm{a}$ & $120 \mathrm{a}$ \\
\hline $\mathrm{F}_{25}$ & $190 \mathrm{~b}$ & $249 \mathrm{c}$ & $221 \mathrm{~b}$ & $224 \mathrm{~b}$ & $81 \mathrm{c}$ & $101 \mathrm{~b}$ & $101 \mathrm{~b}$ & $99 \mathrm{~b}$ \\
\hline $\mathbf{L S D}_{0.05}$ & 3.5 & 5.03 & 9.97 & 12.5 & 3.4 & 8.8 & 9.4 & 11.8 \\
\hline
\end{tabular}

Table 6: Effect of drip-fertigation of different rates of $\mathrm{N}, \mathrm{P}$ and $\mathrm{K}$ fertilizers on days to $50 \%$ silking and cob length (cm)

\begin{tabular}{|c|c|c|c|c|c|c|c|c|}
\hline \multirow{3}{*}{ Treatment } & \multicolumn{4}{|c|}{ No. of days to $50 \%$ Silking } & \multicolumn{4}{|c|}{ Ear length (cm) } \\
\hline & \multicolumn{2}{|c|}{ Autumn } & \multicolumn{2}{|c|}{ Spring } & \multicolumn{2}{|c|}{ Autumn } & \multicolumn{2}{|c|}{ Spring } \\
\hline & 2017 & 2018 & 2018 & 2019 & 2017 & 2018 & 2018 & 2019 \\
\hline $\mathrm{F}_{100}$ & $54.7 \mathrm{a}$ & $55.0 \mathrm{a}$ & 72 & $68.5 \mathrm{a}$ & $17.5 \mathrm{ab}$ & $18.8 \mathrm{a}$ & $16.1 \mathrm{a}$ & $16.2 \mathrm{a}$ \\
\hline $\mathrm{F}_{75}$ & $54.5 \mathrm{ab}$ & $54.0 \mathrm{~b}$ & 72 & $68.5 \mathrm{a}$ & $17.6 \mathrm{ab}$ & $18.4 \mathrm{a}$ & $15.5 \mathrm{~b}$ & $16.3 \mathrm{a}$ \\
\hline $\mathrm{F}_{50}$ & $53.8 \mathrm{~b}$ & $54.0 \mathrm{~b}$ & 72 & $67.75 \mathrm{~b}$ & $18.1 \mathrm{a}$ & $18.2 \mathrm{a}$ & $15.1 \mathrm{~b}$ & $15.8 \mathrm{~b}$ \\
\hline $\mathrm{F}_{25}$ & $52.8 \mathrm{a}$ & $52.5 \mathrm{c}$ & 71 & $66.75 \mathrm{c}$ & $16.9 \mathrm{~b}$ & $16.4 \mathrm{~b}$ & $13.9 \mathrm{c}$ & $14.7 \mathrm{c}$ \\
\hline LSD $_{0.05}$ & 0.93 & 0.65 & ns & .60 & 0.72 & 1.31 & 0.43 & 0.49 \\
\hline
\end{tabular}

Means sharing similar letter are not significantly different from each other ( $p>0.05$ ANOVA followed by Fisher's LSD Test).

$\left.\mathrm{F}_{50}\right)$ did not differ significantly $(p>0.05)$ in both the seasons. Similar results have also been reported by Rop et al. (2019) and Law-Ogbomo et al. (2009). Availability of sufficient nutrients especially nitrogen prolonged vegetative growth period hence increased production of photosynthates and its partitioning to stem that might have increased the plant height (Abera, 2013) and position of main ear on stem as both varietal traits are closely correlated (Gyenes-Hegyi et al., 2002). Significantly lower plant and ear height at $F_{25}$ across seasons and years suggested nutrient deficiency in this treatment that negatively affected the plant growth.

In both experimental years, plants supplied with $F_{25}$ fertigation rate reached $50 \%$ silking stage earlier $(p<0.05)$ (Table 6). Crop reached 50\% silking in 54 and 69 days in autumn and spring, respectively, and the difference can largely be attributed to different type of hybrid and weather conditions in both seasons. Days to $50 \%$ silking increased as
Ear length decreased $(P<0.05)$ as fertigation rate decreased but, in autumn, impact was not significant until rate was lowered beyond $\mathrm{F}_{50}$ (Table 7 ). However, in autumn 2017 longest ears were observed at $F_{50}$. On average, ear length was $17.73 \mathrm{~cm}$ and $15.45 \mathrm{~cm}$ in autumn and spring, respectively. No. of rows ear ${ }^{-1}$ though decreased with decrease in fertilizer rates however difference was not significant $(p>0.05)$ except in spring 2018 where difference reached a significant level (Table 7).This result is usual as number of grain rows ear ${ }^{-1}$ are strongly governed by genetics of the hybrid while environment and growing conditions have a lesser impact on it (Nielsen, 2003). Higher grains row $^{-1}$ were recorded at higher fertigation rate. Greater uptake of $\mathrm{N}, \mathrm{P}$ and $\mathrm{K}$ (Wu et al., 2019), higher assimilate portioning to the seeds coupled with longer vegetative growth period in response to higher drip-fertigation rates might have resulted in higher number of grains (Dawadi and 
Sah, 2012; Sharifi and Namvar, 2016). In autumn 2018 and spring $2019 \mathrm{~F}_{75}$ produced higher grains row ${ }^{-1}$ than $\mathrm{F}_{100}$ that reflects $\mathrm{F}_{75}$ to be the optimized combination of nutrient and moisture availability.

Fresh ear weight $\mathrm{ha}^{-1}$ and grain yield $\left(\mathrm{kg} \mathrm{ha}^{-1}\right)$ was significantly affected $(p<0.05)$ by drip-fertigation rates (Table 8). In autumn 2017, disease incidence and termite attack resulted in substantially lower fresh ear and grain yield. In autumn 2018 fresh ear weight varied between $18066 \mathrm{~kg} \mathrm{ha}^{-1}$ for $\mathrm{F}_{75}$ and $15187 \mathrm{~kg} \mathrm{ha}^{-1}$ for $\mathrm{F}_{25}$ while variation for next season (spring 2019) was from $18849 \mathrm{~kg}$ $\mathrm{ha}^{-1}$ to $12778 \mathrm{~kg} \mathrm{ha}^{-1}$. Across the season and years, grain yield at $\mathrm{F}_{75}$ was statistically similar to that produced at $\mathrm{F}_{100}$ indicating that $25 \%$ incremental nutrients from $\mathrm{F}_{75}$ to $\mathrm{F}_{100}$ were an excessive supply (Jiang et al. 2019). Application of

Table 7: Effect of drip-fertigation of different rates of N, P and $K$ fertilizer on No. of rows ear ${ }^{-1}$ and No. of grains row $^{-1}$

\begin{tabular}{ccccccccc}
\hline \multirow{3}{*}{ Treatment } & \multicolumn{4}{c}{ No. of rows ear $^{-1}$} & \multicolumn{4}{c}{ No. of grains row $^{-1}$} \\
\cline { 2 - 9 } & \multicolumn{2}{c}{ Autumn } & \multicolumn{2}{c}{ Spring } & \multicolumn{2}{c}{ Autumn } & \multicolumn{2}{c}{ Spring } \\
\cline { 2 - 9 } & $\mathbf{2 0 1 7}$ & $\mathbf{2 0 1 8}$ & $\mathbf{2 0 1 8}$ & $\mathbf{2 0 1 9}$ & $\mathbf{2 0 1 7}$ & $\mathbf{2 0 1 8}$ & $\mathbf{2 0 1 8}$ & $\mathbf{2 0 1 9}$ \\
\hline $\mathrm{F}_{100}$ & 16.2 & 14.4 & $17.9 \mathrm{a}$ & 19 & 32.8 & $37.0 \mathrm{a}$ & $29.3 \mathrm{a}$ & $32.97 \mathrm{a}$ \\
$\mathrm{F}_{75}$ & 16.3 & 14.3 & $17.3 \mathrm{ab}$ & 18.83 & 33.2 & $37.1 \mathrm{a}$ & $27.9 \mathrm{a}$ & $35.53 \mathrm{a}$ \\
$\mathrm{F}_{50}$ & 16.3 & 14.3 & $16.5 \mathrm{bc}$ & 18.66 & 33.9 & $36.5 \mathrm{a}$ & $27.5 \mathrm{~b}$ & $32.02 \mathrm{~b}$ \\
$\mathrm{~F}_{25}$ & 16.0 & 14.3 & $15.9 \mathrm{c}$ & 18 & 31.6 & $33.9 \mathrm{~b}$ & $22.7 \mathrm{c}$ & $28.2 \mathrm{~b}$ \\
\hline LSD $_{\mathbf{0 . 0 5}}$ & $\mathbf{n s}$ & $\mathbf{n s}$ & $\mathbf{1 . 0 3}$ & $\mathbf{n s}$ & $\mathbf{n s}$ & $\mathbf{2 . 7 4}$ & $\mathbf{1 . 5 0}$ & $\mathbf{2 . 6 0}$ \\
\hline
\end{tabular}

Means sharing similar letter are not significantly different from each other ( $p>0.05$ ANOVA followed by Fisher's LSD Test).

Table 8: Effect of drip-fertigation of different rates of $N, P$ and $K$ fertilizer on fresh ear weight (kg ha-1) and grain yield (kg ha-1)

\begin{tabular}{ccccccccc}
\hline & \multicolumn{3}{c}{ Fresh ear weight $\left(\mathbf{k g ~ h a}^{-\mathbf{1}}\right)$} & \multicolumn{3}{c}{ Grain yield (kg ha $\left.\mathbf{~}^{-1}\right)$} \\
\cline { 2 - 8 } Treatment & \multicolumn{2}{c}{ Autumn } & \multicolumn{2}{c}{ Spring } & \multicolumn{2}{c}{ Autumn } & \multicolumn{2}{c}{ Spring } \\
\cline { 2 - 8 } & $\mathbf{2 0 1 7}$ & $\mathbf{2 0 1 8}$ & $\mathbf{2 0 1 8}$ & $\mathbf{2 0 1 9}$ & $\mathbf{2 0 1 7}$ & $\mathbf{2 0 1 8}$ & $\mathbf{2 0 1 8}$ & $\mathbf{2 0 1 9}$ \\
\hline $\mathrm{F}_{100}$ & $8845 \mathrm{a}$ & $16428 \mathrm{~b}$ & $18480 \mathrm{a}$ & $18373 \mathrm{a}$ & $6035 \mathrm{a}$ & $10530 \mathrm{~b}$ & $12735 \mathrm{a}$ & $13367 \mathrm{a}$ \\
$\mathrm{F}_{75}$ & $8739 \mathrm{a}$ & $18066 \mathrm{a}$ & $18275 \mathrm{a}$ & $18849 \mathrm{a}$ & $5988 \mathrm{a}$ & $11483 \mathrm{a}$ & $12177 \mathrm{a}$ & $13646 \mathrm{a}$ \\
$\mathrm{F}_{50}$ & $8339 \mathrm{~b}$ & $17950 \mathrm{a}$ & $15494 \mathrm{~b}$ & $15933 \mathrm{~b}$ & $5567 \mathrm{~b}$ & $11384 \mathrm{a}$ & $10103 \mathrm{~b}$ & $11812 \mathrm{~b}$ \\
$\mathrm{~F}_{25}$ & $8214 \mathrm{~b}$ & $15187 \mathrm{c}$ & $14058 \mathrm{~b}$ & $12778 \mathrm{c}$ & $5451 \mathrm{~b}$ & $9597 \mathrm{c}$ & $8905 \mathrm{c}$ & $9507 \mathrm{c}$ \\
\hline LSD $_{0.05}$ & 280 & 594 & 1457 & 1333 & 205 & 582 & 826 & 1011 \\
\hline \multicolumn{2}{l}{ Means sharing similar letter are not significantly different from each other $(p>0.05$ ANOVA followed by Fisher's LSD Test). }
\end{tabular}

Table 9: Response of grain oil, protein and starch contents (\%) to different drip-fertigation rates of $\mathbf{N}, \mathrm{P}$ and $\mathrm{K}$ fertilizers

\begin{tabular}{|c|c|c|c|c|c|c|c|c|c|c|c|c|}
\hline \multirow{3}{*}{ Treatment } & \multicolumn{4}{|c|}{ Oil \% } & \multicolumn{4}{|c|}{ Protein \% } & \multicolumn{4}{|c|}{ Starch \% } \\
\hline & \multicolumn{2}{|c|}{ Autumn } & \multicolumn{2}{|c|}{ Spring } & \multicolumn{2}{|c|}{ Autumn } & \multicolumn{2}{|c|}{ Spring } & \multicolumn{2}{|c|}{ Autumn } & \multicolumn{2}{|c|}{ Spring } \\
\hline & 2017 & 2018 & 2018 & 2019 & 2017 & 2018 & 2018 & 2019 & 2017 & 2018 & 2018 & 2019 \\
\hline $\mathrm{F}_{100}$ & $4.1 \mathrm{a}$ & 4.55 & $4.5 \mathrm{a}$ & $4.3 \mathrm{a}$ & $11.1 \mathrm{a}$ & 12. & $11.7 \mathrm{ab}$ & $11.8 \mathrm{a}$ & 53.4 & & $52.2 \mathrm{~A}$ & $51.9 \mathrm{a}$ \\
\hline $\mathrm{F}_{75}$ & $4.0 \mathrm{ab}$ & 4.3 & $4.6 \mathrm{a}$ & $4.4 \mathrm{a}$ & $10.6 \mathrm{~b}$ & & $2 a$ & 12 & 53.9 & $\mathrm{~b}$ & $2 \mathrm{~B}$ & $51.6 \mathrm{a}$ \\
\hline $\mathrm{F}_{50}$ & $4.0 \mathrm{ab}$ & 4.35 & $4.1 \mathrm{~b}$ & $4.3 \mathrm{a}$ & $10.3 \mathrm{bc}$ & $12.7 \mathrm{a}$ & $11.2 \mathrm{~b}$ & $12.0 \mathrm{a}$ & 54.1 & $50.8 \mathrm{a}$ & $50.4 \mathrm{~B}$ & $51.1 \mathrm{a}$ \\
\hline $\mathrm{F}_{25}$ & $3.9 \mathrm{~b}$ & 4.38 & $4.1 \mathrm{~b}$ & $4.0 \mathrm{~b}$ & $10.1 \mathrm{c}$ & $11.3 \mathrm{~b}$ & $11.6 \mathrm{~b}$ & $11.0 \mathrm{~b}$ & 53.0 & $51.3 \mathrm{a}$ & $48.7 \mathrm{C}$ & $49.4 \mathrm{~b}$ \\
\hline LSD $_{0.05}$ & 0.16 & ns & 0.32 & 0.26 & 0.33 & 0.61 & 0.54 & 0.73 & ns & 1.67 & 1.45 & 1.50 \\
\hline
\end{tabular}

Means sharing similar letter are not significantly different from each other ( $p>0.05$ ANOVA followed by Fisher's LSD Test).

Table 10: Effect of different rate of N, P and K fertilizer on Partial Factor Productivity

\begin{tabular}{lccccc}
\hline \multirow{2}{*}{ Treatment } & Total nutrient applied & \multicolumn{3}{c}{ Partial Factor Productivity (PFP) } \\
\cline { 3 - 6 } & $\left(\mathbf{N}+\mathbf{K}_{\mathbf{2}} \mathbf{O}+\mathbf{P}_{\mathbf{2}} \mathbf{O}_{\mathbf{5}}\right)$ & \multicolumn{2}{c}{ Autumn } & \multicolumn{2}{c}{ Spring } \\
\cline { 3 - 6 }$\left(\mathbf{k g ~ h a}^{-1}\right)$ & 492 & 12.3 & 21.4 & 25.9 & 27.2 \\
\hline $\mathrm{F}_{100}$ & 369 & 16.2 & 31.2 & 33.0 & 37.0 \\
$\mathrm{~F}_{75}$ & 246 & 22.7 & 46.3 & 41.1 & 48.1 \\
$\mathrm{~F}_{50}$ & 123 & 44.4 & 78.1 & 72.5 & 77.3 \\
$\mathrm{~F}_{25}$ & & &
\end{tabular}


nutrients and water at the same time in drip-fertigation improved the water and fertilizer use efficiency and minimized nutrient losses (Wu et al., 2019) resulting in realization of higher yield at lower than recommend fertilizer rate. Results are in agreement with Jiang et. al. (2019), Yan et al. (2014) and Seggewiss and Jungk (1988) who reported that yield increased efficiently in response to increase in N, P or K up to an optimal rate and after that, the rate of yield increase slowed down before reaching a plateau. It is also remarkable to note that, on average, yield reduced by $16 \%$ and $30.1 \%$ in autumn and spring, respectively, as fertilizer rate decreased from $100 \%$ recommended to mere $25 \%$ of recommended $\mathrm{N}, \mathrm{P}$ and $\mathrm{K}$ nutrient rates. More profound impact in spring season may largely be attributed to longer growth period in spring than autumn that required more nutrients to produce higher yield.

\section{Grain quality}

Data regarding grain quality parameters is presented in Table 9. In autumn 2017, oil contents remained stable for $\mathrm{F}_{100}, \mathrm{~F}_{75}$ and $\mathrm{F}_{50}$ and decreased $(p<0.05)$ for $\mathrm{F}_{25}$ while impact in autumn 2018 was non-significant. Sinha et al. (2017) also found non-significant impact of different dripfertigation levels $(100 \%, 80 \%$ and $60 \%$ of recommended dose) on oil contents in sunflower. While in spring, higher oil contents were greatest at $F_{75}$ that decreased on both directions. In all four instances of experiment, $\mathrm{F}_{25}$ produced lowest oil contents. Results are in agreement to Wang and Frei (2011) who concluded that oil contents in crops decrease in response to abiotic stresses. Protein contents were significantly affected $(P<0.05)$ by fertilizer rates. Higher protein contents were recorded from $\mathrm{F}_{75}$ except in autumn-2017 where $F_{100}$ produced highest protein contents. In autumn 2018 and spring 2019, protein contents were maintained even at $\mathrm{F}_{50}$ but decreased significantly afterward in all four growing seasons. Incremental increase of fertilizer especially $\mathrm{N}$ for plant growth increased the protein contents in grain (Sharifi and Namvar, 2016). Starch contents responded to drip-fertigation significantly $(p<0.05)$ in three growing instances while remained unaffected in autumn 2017. In autumn 2018, highest starch contents were recorded at $F_{25}$ that decreased with increase in fertilizer rate. While in spring season, starch contents decreased with decrease in drip-fertigation rate and least amount of starch were produced by $\mathrm{F}_{25}$ in both years.

\section{Partial factor productivity (PFP)}

Data regarding PFP is depicted in Table 10. It revealed that PFP decreased as the nutrient application (fertilizer rate) increased. Results are in agreement to those previously reported by Darwish et al. (2006), Fontes et al. (2010) and
Ierna et al. (2011). PFP was lower in autumn-2107 due to incidence of stalk rot and termite attack (data not included) that resulted in substantially lower yield. In all the four seasons, highest PFP was recorded at $25 \%$ of the recommended fertilizer doses though higher fertilizer use efficiencies at lower application rates are not necessarily economically effective (Roberts, 2008). Decline in fertilizer productivity in autumn was steeper $(30.5 \%$ and $27.5 \%)$ compared to spring season $(21.5 \%$ and $24.5 \%)$ with decrease in fertilizer rate from $F_{75}$ to $F_{50}$ and $F_{50}$ to $F_{25}$, respectively. This might have been due to the difference in prevailing climate conditions in both the seasons and its impact on plant growth resulting in differential nutrient requirements and uptake rate.

\section{Conclusion}

In current study, impact of different drip-fertigation rates of $\mathrm{N}, \mathrm{P}$ and $\mathrm{K}$ fertilizers was evaluated on maize yield and quality. Results suggested that yield and yield contribution attributes improved by incremental application of NPK fertilizers. Different attributes i.e. number of ears $\mathrm{ha}^{-1}$, cob length, number of grains row $^{-1}$ remained higher at $\mathrm{F}_{75}$ most of the instances. Similarly, fresh ear weight and grain yield $\left(\mathrm{kg} \mathrm{ha}^{-1}\right)$ at $\mathrm{F}_{75}$ were also higher or similar to that produced by $\mathrm{F}_{100}$ clearly indicating that additional $25 \% \mathrm{~N}, \mathrm{P}$ and $\mathrm{K}$ fertilizers were excessive that can be saved successfully without compromising yield and quality. Judicious and efficient application of NPK improved the grain quality in terms of oil, protein and starch contents (\%) even at lower application rate. Summarizing the results, under drip-fertigation system, higher grain yield of better quality can be achieved by applying $75 \%$ of the recommended fertilizers in area of study.

\section{References}

Abera, T., T. Debele and D. Wegary. 2017. Effects of varieties and nitrogen fertilizer on yield and yield components of maize on farmers field in mid altitude areas of Western Ethiopia. International Journal of Agronomy. ID 4253917. https://doi.org/10.1155/2017/4253917

Afzal, N. and S. Ahmad. 2009. Agricultural input use efficiency in Pakistan: key issues and reform areas. Research briefing. Natural Resources Division, Pakistan Agricultural Research Council, Islamabad, Government of Pakistan. Volume 1, No. 3.

Azad, N., J. Behmanesh, V. Rezaverdinejad, F. Abbasi and M. Navabian. 2018. Developing an optimization model in drip fertigation management to consider environmental issues and supply of plant requirements. Agricultural Water Management. 208: 344-356. 
Darwish, T.M., T.W. Atallah, S. Hajhasan and A. Haidar. 2006. Nitrogen and water use efficiency of fertigated processing potato. Agricultural Water Management 85: 95-104.

Dawadi, D.R. and S.K Sah. 2012. Growth and yield of hybrid maize (Zea mays L.) in relation to planting density and nitrogen levels during winter season in Nepal. Tropical Agricultural Research. 23: 218-27.

Dolan M.S., C.E. Clapp, R.R. Allmaras, J.M. Baker and J.A.E. Molina. 2006. Soil organic carbon and nitrogen in a Minnesota soil as related to tillage, residue and nitrogen management. Soil Tillage Research 2006: 89: 221-31.

Eckstein, D., M.L. Hutfil and Winges, M. 2019. Global climate risk index. Briefing paper, Germanwatch. Bonn, Germany.

Fanish, S.A., P. Muthukrishnan and P. Santhi. 2011. Effect of drip fertigation on field crops -a review. Agricultural Review 32:14-25.

FAO. 2017. CropWat 8.0 for windows. Crop and water division. Accessed on December 02, 2019 from http://www.fao.org/land-water/databases-andsoftware/cropwat/en/.

Fontes, P.C.R., H. Braun, C. Busato and P.R. Cecon. 2010. Economic optimum nitrogen fertilization rates and nitrogen fertilization rate effects on tuber characteristics of potato cultivars. Potato Research 53: 167-179.

GoP. 2014. Aquatic Ecosystem. p.73-103. In: The Environment and Climate Change Outlook of Pakistan. Climate Change Division, Ministry of Climate Change, Government of Pakistan. Islamabad. Accessed on December 5, 2019 from $\mathrm{http} / / /$ www.mocc.gov.pk/pubDetails.aspx.

Gyenes-Hegyi, Z., I. Pók, L. Kizmus, Z. Zsubori, E. Nagy and L. C. Marton. 2002. Plant height and height of the main ear in maize (Zea mays L.) at different locations and different plant densities. Acta Agronomica Hungarica 50: 75-84.

Ierna, A., G. Pandinob, S. Lombardob and G. Mauromicaleb. 2011. Tuber yield, water and fertilizer productivity in early potato as affected by a combination of irrigation and fertilization. Agricultural Water Management 101: 35-41.

Iqbal, Z., M. Yaqub, M. Akram and R. Ahmad. 2013. Phosphorus fertigation: A technique for enhancing $\mathrm{P}$ fertilizer efficiency and yield of wheat and maize. Soil \& Environment 32: 146-151.

Jiang, W., L. Xiaohu, W. Xiukang, L. Yang and Y. Yin. 2019. Improving phosphorus use efficiency and optimizing phosphorus application rates for maize in the northeast plain of China for sustainable agriculture. Sustainability 11, 4799; doi: 10.3390/su11174799.
Khaliq, T., A. Ahmad, A. Hussain and M.A. Ali. 2008. Impact of nitrogen rate on growth, yield and radiation use efficiency of maize under varying environments. Pakistan Journal of Agricultural Science 45: 1-7.

Law-Ogbomo, K., E. Kolapole and J.E. Law-Ogbomo. 2009. Performance of Zea mays as influenced by NPK fertilizer application. Notulae Scientia Biologicae 1:5962.

Lekakis, E.H., P.E. Georgiou, A. Pavlatou-Ve and V.Z. Antonopoulos. 2011. Effects of fixed partial root-zone drying irrigation and soil texture on water and solute dynamics in calcareous soils and corn yield. Agricultural Water Management 101: 71-80.

Nielsen, R. L. 2003. Ear initiation \& size determination in corn. Purdue University Department of Agronomy. Accessed on December 8, 2019 from http://www.kingcorn.org/news/articles.03/EarSize0609.html.

Pablo, R.G., M.K. O’Neill, B.D. Mccaslin, M.D. Remmenga, J.G. Keenanand and B.M. Onken. 2007. Evaluation of corn grain yield and water use efficiency using subsurface drip irrigation. Journal of Sustainable Agriculture 30: 153-172.

Prihar, S.S., P.R. Gajri, D.K. Benbiand and V.K. Arora. 2000. Intensive Cropping: Efficient Use of Water, Nutrients and Tillage. The Haworth Press, New York. Qureshi, A.L., M. A. Gadehi, A.A. Mahessar, N.A. Memon, A.G. Soomro and A.H. Memon. 2015. Effect of drip and furrow irrigation systems on sunflower yield and water use efficiency in dry area of Pakistan. American-Eurasian Journal of Agriculture and Environmental Science15: 1947-1952.

Qureshi, A.S., P. McCornick, A. Sarwar and B.R. Sharma. 2009. Challenges and prospects of sustainable groundwater management in the Indus Basin, Pakistan. Water Resource Management 24: 1551-1569.

Roberts, T. 2008. Improving nutrient use efficiency. Turkish Journal of Agriculture and Forestry 32: 177-182.

Rop, K., George, N.K., M. Damaris, N. Njomo and I. Michira. 2019. Evaluating the effects of formulated nano-NPK slow release fertilizer composite on the performance and yield of maize, kale and capsicum. Annals of Agricultural Sciences 64: 9-19.

Sampathkumar, T. and B.J. Pandian.2011. Nutrient uptake rate and relationship with grain yields of hybrid maize under drip fertigation. Madras Agricultural Journal 98: 151-153.

Seggewiss, B. and A. Jungk. 1988. Influence of potassium dynamics at the soil-root interface on magnesium uptake of plants .Zeitschrift fuer Pflanzenernaehrung und Bodenkunde (Germany, F.R.) 151: 91-96. 
Sharifi, R.S. and A. Namvar. 2016. Effects of time and rate of nitrogen application on phenology and some agronomical traits of maize (Zea mays L.). Biologija 62: 35-45.

Sinha, I., G.S. Buttar and A.S. Brar. 2017. Drip irrigation and fertigation improve economics, water and energy productivity of spring sunflower (Helianthus annuus L.) in Indian Punjab. Agricultural Water Management 185: 58-64

Ünlü, M., R. Kanber, D.L. Koc, S. Tekinand and B. Kapur. 2011. Effects of deficit irrigation on the yield and yield components of drip irrigated cotton in a mediterranean environment. Agricultural Water Management 98: 597605.

Wan, S., Y. Jiao, Y. Kang, W. Hu, S. Jiang, J. Tan, and W. Liu. 2012. Drip irrigation of waxy corn (Zea mays L. var. ceratina Kulesh) for production in highly saline conditions. Agricultural Water Management 104: 210220.

Wang, Y. and M. Frei. 2011. Stressed food-The impact of abiotic environmental stresses on crop quality.

Agriculture, Ecosystems \& Environment 141: 271-286.
Van Cleemput, O. 2000. Final Annual Co-ordination Meeting of Regional TC Project RAW/5/007 on Fertigation for Improved Water Use Efficiency and Crop Yield, November 20-24. IAEA, Vienna.

Wu, D., X. Xinxing, Y. Chena, H. Shao, E. Sokolowski and G. Mia. 2019. Effect of different drip fertigation methods on maize yield, nutrient and water productivity in two-soils in Northeast China. Agricultural Water Management 213: 200-211.

Yan, D., K. Chen, W. Teng, A. Zhan, Y.P. Tong, G. Feng, Z.L. Cui, F.S. Zhang and X.P. Chen. 2014. Is the inherent potential of maize roots efficient for soil phosphorus acquisition. PLoS ONE 9, e90287.

Zhang, F., J. Wang, W. Zhang, Z. Cui, W. Ma, X. Chen and R. Jiang. 2008. Nutrient use efficiencies of major cereal crops in China and measures for improvement. Acta Pedologica Sinica 45: 915-924. 